\title{
Ca 拮抗薬（アムロジピン）が培養ヒト歯肉線維芽細胞に及ぼす影響
}

\author{
江連雅孝*1 稲田全規*1 橋本 尚詞*2 \\ 石川 博*2 河村 博*3 鴨井久一*1 \\ ${ }^{* 1}$ 日本歯科大学歯学部歯周病学教室 \\ $* 2$ 東京慈恵会医科大学医学部解剖学講座第二 \\ ${ }^{* 3}$ 日本歯科大学歯学部内科学教室 \\ (1999 年 10 月 9 日受理)
}

\author{
Ca Channel Blocker (Amlodipine) Effects on Human \\ Gingival Fibroblasts in Tissue Culture \\ Masataka Ezure*1, Masaki Inada*1, Hisashi Hashimoto*2, \\ Hiroshi Ishikawa*2, Hiroshi Kawamura*3 and Kyuichi Kamoi*1 \\ ${ }^{* 1}$ Department of Periodontology, School of Dentistry at Tokyo, The Nippon Dental University \\ ${ }^{* 2}$ Department of Anatomy (II), The Jikei University School of Medicine \\ ${ }^{* 3}$ Department of Internal Medicine, School of Dentistry at Tokyo The Nippon Dental University \\ Accepted for publication 9 October 1999
}

The effects of amlodipine, a third generation dihydropyridine calcium antagonist, on human gingival fibroblasts were investigated in vitro. The growth of fibroblasts obtained from an intact donor was inhibited by amlodipine in a concentration-dependent manner. Amlodipine reduced the growth rate, DNA synthesis and oxygen consumption of the fibroblasts. Fuotherarore, the addition of amlodipine in culture media changed the spindle-like appearance of adherent fibeoblasts to round shapes, caused cell detachment from the culture plate and decreased cell viability. In adclition, the presence of amlodipine prevented the fibroblasts floating in suspension from attaching to the culture plate and severely decreased the viable cell rate. These results indicate that amlodipine has no profitable action, but shows inhibitory effect on human gingival fibroblast in vitro. This finding suggests that gingival hyperplasia induced by amlodipine is not ascribed to the direct action of amlodipine on gingival fibroblasts. J. Jpn. Soc. Periodontol., 41: 371 379, 1999.

Key words : amlodipine, human gingival fibroblasts, gingival hyperplasia

要旨：本研究はジヒドロピリジン系の第三世代 Ca 拮抗薬であるアムロジピンが培養ヒト歯肉線維芽細胞に及 ぼす影響を検討した。アムロジピンは歯肉線維芽細胞の増殖を濃度依存的に抑制した。アムロジピンによって歯 肉線維芽細胞の細胞分裂，DNA 合成，酸素消費が抑制された。アムロジピンによって細胞の大きさが小さくな り，形態も紡鍾形から円形に変化した。アムロジピンの存在下で細胞の接着率は低下し，これに伴って生細胞率 が減少した。以上のことより，アムロジピンは培養ヒト歯肉線維芽細胞の代謝を抑え増殖を抑制することが明ら かとなった。これらより, Ca 拮抗薬による歯肉増殖の発症は, Ca 拮抗薬の歯肉線維芽細胞への直接作用による 増殖促進が引き起こされた結果として生じるのではない可能性を示唆している。

索引用語：アムロジピン, ヒト歯肉線維芽細胞, 歯肉増殖症 


\section{緒言}

薬物の副作用による歯肉増殖症については 1939 年 の $\mathrm{Kimball}^{1)}$ が抗てんかん薬であるフェニトインによ る報告以来，免疫抑制剤のサイクロスポリン $\mathrm{A}^{2)}, \mathrm{Ca}$ 拮抗薬のニフェジピン ${ }^{3,4)}$ 等, 多数の報告がある。こ れら歯肉増殖症の発症は口腔衛生状態の改善による予 防および再発防止の報告 ${ }^{5 \sim 7}$ があるが，他方，プラー ク等の除去では発症を抑制できないとの報告8 11)もあ り，歯周病原性因子と歯肉増殖症の進行に関する一定 の見解は得られていない。また，服用量や服用期間と 歯肉増殖症の発症の機序 ${ }^{5 \sim 7,12)}$ や重症度 ${ }^{13 \sim 15)}$ との関連 が検討されたが，現在のところ明確な指標は見い出さ れていない。とりわけ $\mathrm{Ca}$ 拮抗薬は, 循環器系疾患の 治療薬として用いられていることから中高年者に高頻 度に服用され，歯肉増殖症を含む歯周病の増悪因子と しての関連が論じられてきた。さらに，ジヒドロピリ ジン系薬剤の第一世代の Ca 拮抗薬であるニフェジピ ンの内科的なその副作用を改善するために，新たに開 発された $\mathrm{Ca}$ 拮抗薬でも歯肉増殖症が発症する ${ }^{16 ~ 19)}$ と 報告され, $\mathrm{Ca}$ 拮抗薬の基本的な化学構造式に由来し て歯肉増殖症が発症することが推察される。ジヒドロ ピリジン系の第三世代のCa 拮抗薬として開発さたア ムロジピンは, 高血圧疾患に対する降圧効果は緩徐で あるが長時間持続することを特徴とし，使用頻度が増 加している。アムロジピンの優れた薬理作用と副作用 の減少により，歯肉増殖症の発症も軽減することが期 待されたが, その後の研究により歯肉増殖症の発症が 確認された 20 22)。しかしながら，アムロジピンによ る歯肉増殖症の発症機序を検討した報告は未だ見られ ない。そこで本研究はアムロジピンがヒト正常歯肉由 来の線維芽細胞に及ぼす影響を検討した。

\section{材料および方法}

\section{ヒト歯肉線維芽細胞の培養}

ヒト歯肉線維芽細胞は日本歯科大学歯学部附属病院 に来院した患者より十分にインフォームドコンセント を得て採取し，以下の方法で培養することにより得ら れた。歯肉組織片を採取後, リン酸緩衝液 $[\mathrm{PBS}$ () : Ca free phosphaté-buffered saline] で数回洗浄 し，歯肉組織を細片化して $10 \%$ ウシ胎仔血清 (FBS), Penicillin $(50 \mathrm{U} / \mathrm{m} l)$-Streptomycin (50 $\mu \mathrm{g} / \mathrm{m} l)$ (GIBCO 社・米国), $\mathrm{NaHCO}_{3}(2.1 \mathrm{~g} / l$ ) を含む $\alpha$-Minimum Essential Medium ( $\alpha$-MEM) (GIBCO 社・米国) を入れた培養シャーレ上に静置
し, 増殖してきた歯肉線維芽細胞を Out Growth 法 ${ }^{23)}$ を用いて分離・培養した。細胞は $\alpha-\mathrm{MEM}$ を成長培 地として用い， $5 \% \mathrm{CO}_{2}$ を含む気相下で $37^{\circ} \mathrm{C}$ にて継 代培養した。実験には 5 代から 7 代まで継代した細胞 を正常歯肉線維芽細胞として供した。

1) 細胞増殖曲線の作成

$60 \mathrm{~mm}$ 培養シャーレに $1.2 \times 10^{5}$ 個の細胞を播種 し, 24 時間後から， $1 \times 10^{-7} \sim 1 \times 10^{-4} \mathrm{~mol} / l$ (以下 M）のアムロジピンを添加した。アムロジピン処理濃 度はニフェジピンを用いた西川ら ${ }^{24)}$ の報告を参考とし 決定した。全実験に使用したアムロジピンは希釈溶媒 に溶解後, 各最終濃度となるように培養液を調整し た。コントロールは処理群と同量の溶媒のみを添加し て実験を行った。添加後 24，48，72，96，120 時間目 に $0.1 \%$ Trypsin-0.02\% EDTA/PBS（一）にて細 胞を剥離後，遠沈管に回収し，1,000 回転で 10 分間 遠心後，血球計算盤にて細胞数を求めた。また， 72 時間後の細胞数より細胞増殖率を計算した。

2) DNA 合成の測定

DNA 合成能は ELISA 法（Enzyme-linked immunosorbent assay）により測定した。歯肉線維芽細胞 を 96 穴プレート中に $1 \times 10^{3}$ cells/well の細胞数で播 種し，培養開始 24 時間後にアムロジピンを $10^{-7}$ $10^{-4} \mathrm{M}$ 添加し， 72 時間作用させた。ELISA 法は Cell proliferation assay system（Amersham 社製，米国) を用いた。その原理は細胞培養液に Bromodeoxyuridine (BrdU) と 1/10 量の fluoro-deoxyuridine を加 えて 2 時間インキュベートし，DNA 合成期の細胞核 に BrdUを取り込ませた後，アセトン/エタノールで 細胞を固定する。PBS（一）で洗浄後，3\% BSA で ブロッキングし，ヌクレアーゼの存在下に抗 BrdU 抗体と反応させ，さらに洗浄後，ペルオキシダーゼ標 識の二次抗体と反応させる。その後，ペルオキシダー ゼの発色基質溶液で一定時間反応させた後，反応を停 止させ，溶液の $410 \mathrm{~nm}$ における吸光度を測定する方 法である。実験はこのプロトコールに従って行い, $410 \mathrm{~nm}$ の吸光度はマイクロプレートリーダー [MPR -A $4 \mathrm{i}$ (東ソー社製・東京) ] を用いて測定した。

3）細胞培養液中における溶存酸素量の測定

アムロジピンによる歯肉線維芽細胞の基礎代謝の変 化を, 細胞の酸素消費量を指標として検討した。細胞 培養液中の溶存酸素量の測定にはクラーク式電極法を 用いた溶存酸素測定装置：DOX-10（ダイキン社製, 茨城）を用いた ${ }^{25)}$ 。歯肉線維芽細胞を $0.1 \%$ Try$\mathrm{psin} / 0.02 \%$ EDTA 含有 PBS（一）にて剥離後, 細 胞を遠沈管に回収して 1,000 回転で 10 分間遠心した。 得られた細胞を $1 \times 10^{6}, 2 \times 10^{6}, 4 \times 10^{6} \mathrm{cells} / \mathrm{m} l$ の濃 
度で細胞懸濁液を調整し, 細胞濃度による酸素消費量 の検討に用いた。また, $2 \times 10^{6} \mathrm{cells} / \mathrm{m} l$ に調整された 歯肉線維芽細胞にアムロジピンを $10^{-5}, 10^{-4} \mathrm{M}$ で作 用させ, 酸素消費量の変化を検討した。各実験におけ る細胞懸濁液は調整直後に実験に使用し, 測定開始か ら 60 分間の酸素消費量の変化を解析した。

4）歯肉線維芽細胞の形態変化に対する検討

アムロジピンによる細胞形態の変化を検討するため に, 細胞播種時にアムロジピンを添加する群（同時添 加群）と播種 24 時間後にアムロジピンを添加する群 （接着後添加群）に分け, 実験を行った。アムロジピ ンの添加濃度は $10^{-4} \mathrm{M}$ とし, 細胞の形態と接着に及 ぼす影響を，アムロジピン添加後から 1，6，24 時間 後に位相差顕微鏡を用い観察した。

5）接着性細胞率とトリパンブルー排斥試験

4）と同様の実験においてアムロジピン添加 24 時間 後の培養上清に検出される細胞を浮遊細胞画分とし, 付着細胞は $0.1 \%$ Trypsin $/ 0.02 \%$ EDTA 含有 PBS （一）で剥離して付着細胞画分とした。両画分の細胞 数を血球計算盤を用いてカウントし, 付着細胞/全細 胞数により接着率を求めた。生存細胞率の検討は, ト リパンブルー排斥試験 ${ }^{26)} に よ り$ 求めた。両画分の細胞 懸濁液 $(1.5 \mathrm{ml})$ に $0.4 \%$ トリパンブルー染色液 $(0.5 \mathrm{ml})$ を混合し, 染色陽性を死細胞, 染色陰性を 生細胞として全細胞に対する生細胞の割合を生存細胞 率とした。

\section{統計学的検索}

統計処理にはstudentの $t$-検定を用いた。

\section{結果}

\section{1）アムロジピンの細胞増殖に及ぼす影響}

アムロジピンが歯肉線維芽細胞の増殖に及ぼす作用 を検討するために，アムロジピン濃度別の細胞増殖曲 線を作成した（図 1)。歯肉線維芽細胞の増殖は対照 群と比較してアムロジピン $10^{-7} \mathrm{M}$ の添加群より抑制 され， $10^{-4} \mathrm{M}$ 添加群において最も顕著に抑制された。 また，細胞増殖率の結果から，細胞増殖はアムロジピ ン $10^{-7} \mathrm{M}$ 添加群で $26.8 \%(\mathrm{p}<0.05) ， 10-6 \mathrm{M}$ で $33.3 \%(\mathrm{p}<0.05), 10^{-5} \mathrm{M}$ で $38.3 \% （ \mathrm{p}<0.01 ）$ 抑制 され， $10^{-4} \mathrm{M}$ の添加では $49.4 \%(\mathrm{p}<0.001)$ となり, 増殖抑制は濃度依存的であった（図 2)。

2）アムロジピン添加による DNA 合成能の変化

アムロジピン添加による歯肉線維芽細胞の DNA 合 成能の変化を ELISA 法を用いて検討した結果，歯肉 線維芽細胞の DNA 合成はアムロジピンの濃度依存的 に抑制された。各作用濃度におけるDNA 合成の抑制

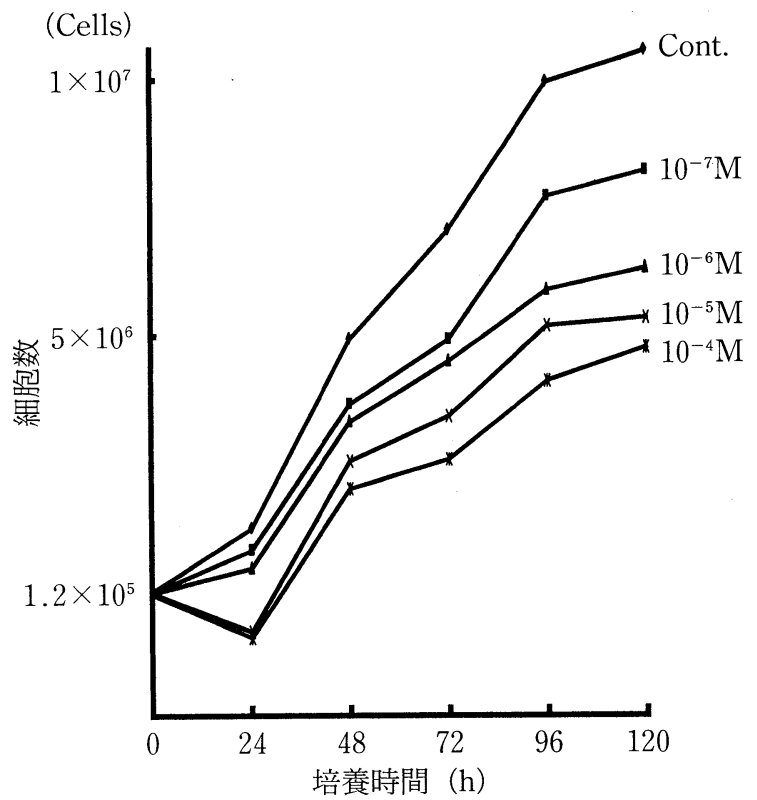

図 1 アムロジピン処理による細胞増殖曲線の変化 $(\mathrm{n}=3)$

アムロジピン処理による細胞増殖の抑制傾向が認 められた。

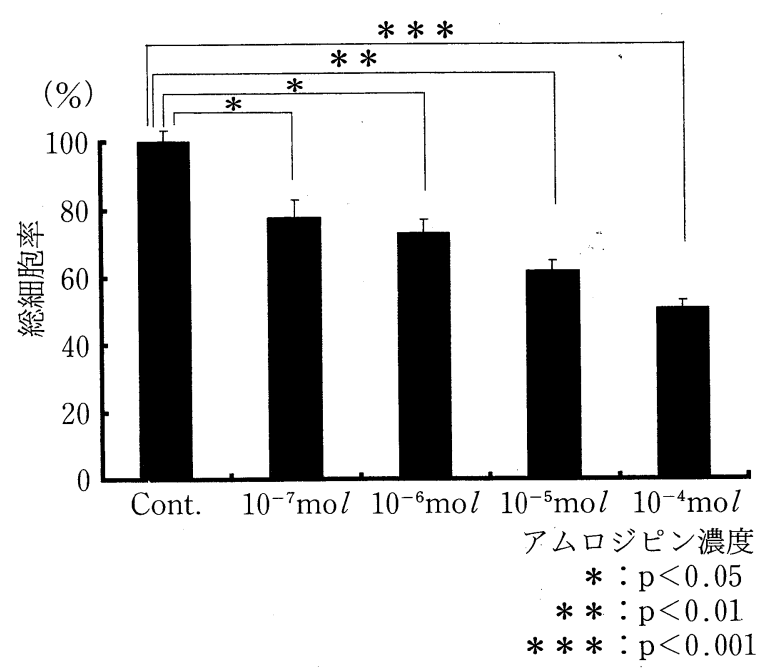

図 2 細胞増殖の抑制 $(n=3)$

アムロジピン処理濃度依存的に細胞増殖の抑制が 認められた。

は， $10^{-7} \mathrm{M}$ 添加群で $10.2 \%(\mathrm{p}<0.05), 10^{-6} \mathrm{M}$ 添加 群で $25.8 \%(\mathrm{p}<0.01) ， 10^{-5} \mathrm{M}$ 添加群で $31.7 \%$, $10^{-4} \mathrm{M}$ 添加群では $52.3 \%$ であった（図 3)。これらの 結果は, 細胞増殖曲線で得られたアムロジピン添加に よる歯肉線維芽細胞の増殖抑制の結果と関連性が認め られた。 
3）アムロジピン添加による歯肉線維芽細胞の酸素 消費量の変化

細胞の代謝変化を細胞呼吸による酸素消費量の変化 としてとらえるために, 細胞培養液中の酸素消費量の 測定をおこない, 歯肉線維芽細胞の基礎代謝を検討し た（図 4-1）。

細胞数を段階的に増加させ，容存酸素量を測定した 結果から, $1 \times 10^{6}$ 個 $/ \mathrm{m} l$ の細胞数で 1 時間に 0.30 $\mathrm{ppm}, 2 \times 10^{6}$ 個 $/ \mathrm{m} l$ の 細胞数で $0.69 \mathrm{ppm}, 4 \times 10^{6}$ 個 $/ \mathrm{m} l$ の細胞数で $0.95 \mathrm{ppm}$ の酸素消費が確認され, 細胞数に比例した酸素消費量の増加が認められた。ま た，アムロジピン添加によりこれらの細胞呼吸は抑制 され, 対照群と比較して $10^{-5} \mathrm{M}$ 添加群で $53.9 \%$, $10^{-4} \mathrm{M}$ 添加群で $55.2 \%$ の酸素消費の抑制が認められ

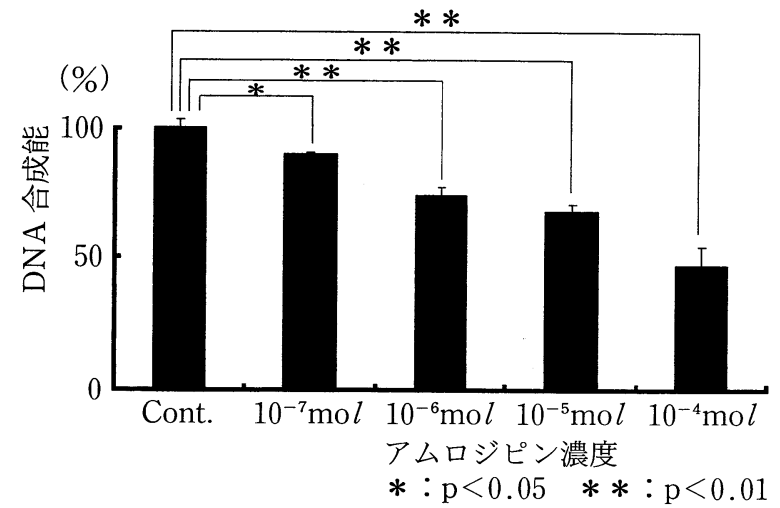

図 3 DNA 合成能の変化 $(n=3)$

アムロジピン処理濃度依存的に DNA 合成の阻害 が認められた。

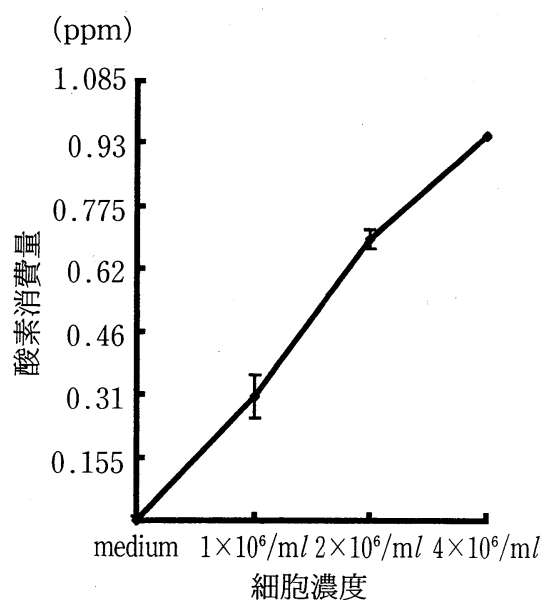

図 4-1 細胞数による酸素消費量の 変化 $(n=3)$

細胞数に比例した酸素消費量の増 加が認められた。
た(図 4-2)。

4）アムロジピンによる歯肉線維芽細胞の形態的変 化

歯肉線維芽細胞の播種後 24 時間に, 対照群では経 時的に接着する細胞が増加した。一方, 播種時にアム ロジピンを添加した同時添加群では, 播種 24 時間後 でもプレート上に接着する細胞はほとんど認められな かった（図 5-1）。また，歯肉線維芽細胞がプレート 上に接着した後にアムロジピンを添加した接着後添加 群では作用時間に依存して細胞が縮小し, 円形の細胞 や浮遊性の細胞が増加した。対照群では紡錐形の典型 的な歯肉線維芽細胞が認められた（図 5-2）。

同時添加群における細胞接着率は, 対照群では 98\%であるのに対して 10\% 以下であり，細胞接着の 有意な減少を示した。 $(\mathrm{p}<0.001)$ 。一方，接着後添 加群における細胞接着率は, 対照群の $98 \%$ に対して $55 \%$ であり，細胞接着は有意に減少した。（ $<<$ 0.001)。アムロジピン添加による細胞接着の減少は, 添加方法に関わらず認められたが，同時添加群におい てより顕著であった。（p<0.001）（図 6)。

5）トリパンブルー排斥試験の検討

トリパンブルー排斥試験による生細胞率はアムロジ ピン同時添加群では $28.3 \pm 4.3 \%$, 接着後添加群では $61.4 \pm 0.65 \%$ であり, 両群とも対照群と比較して有 意に減少し同時添加群においてより顕著であった $(\mathrm{p}<0.001)$ (図 7)。

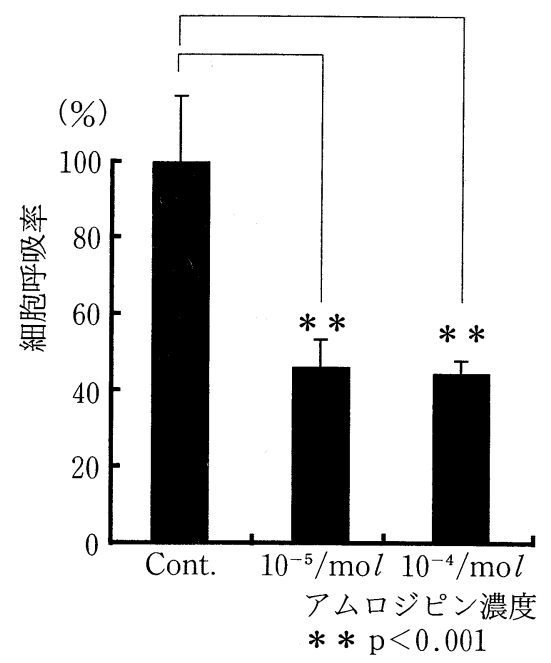

図 4-2 アムロジピンによる細胞呼 吸の抑制 $(\mathrm{n}=3)$

アムロジピン処理濃度依存的に細 胞の酸素消費は低下し，呼吸の抑制 が認められた。 
$1 \mathrm{hr}$
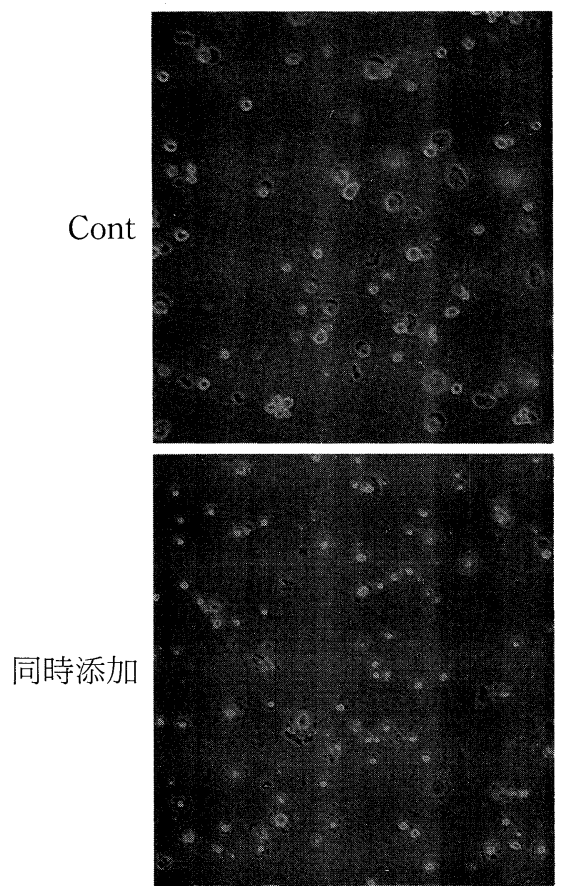

図 5-1 アムロジピンによる歯肉線維芽細胞の形態変化 $(\mathrm{n}=3)$

コントロール； 1 時間後細胞が付着し始める。6 時間後細胞が付着をし極性化が除々に認められ る。24 時間後細胞は線維芽細胞の特徴的形態を示している。

$1 \mathrm{hr}$
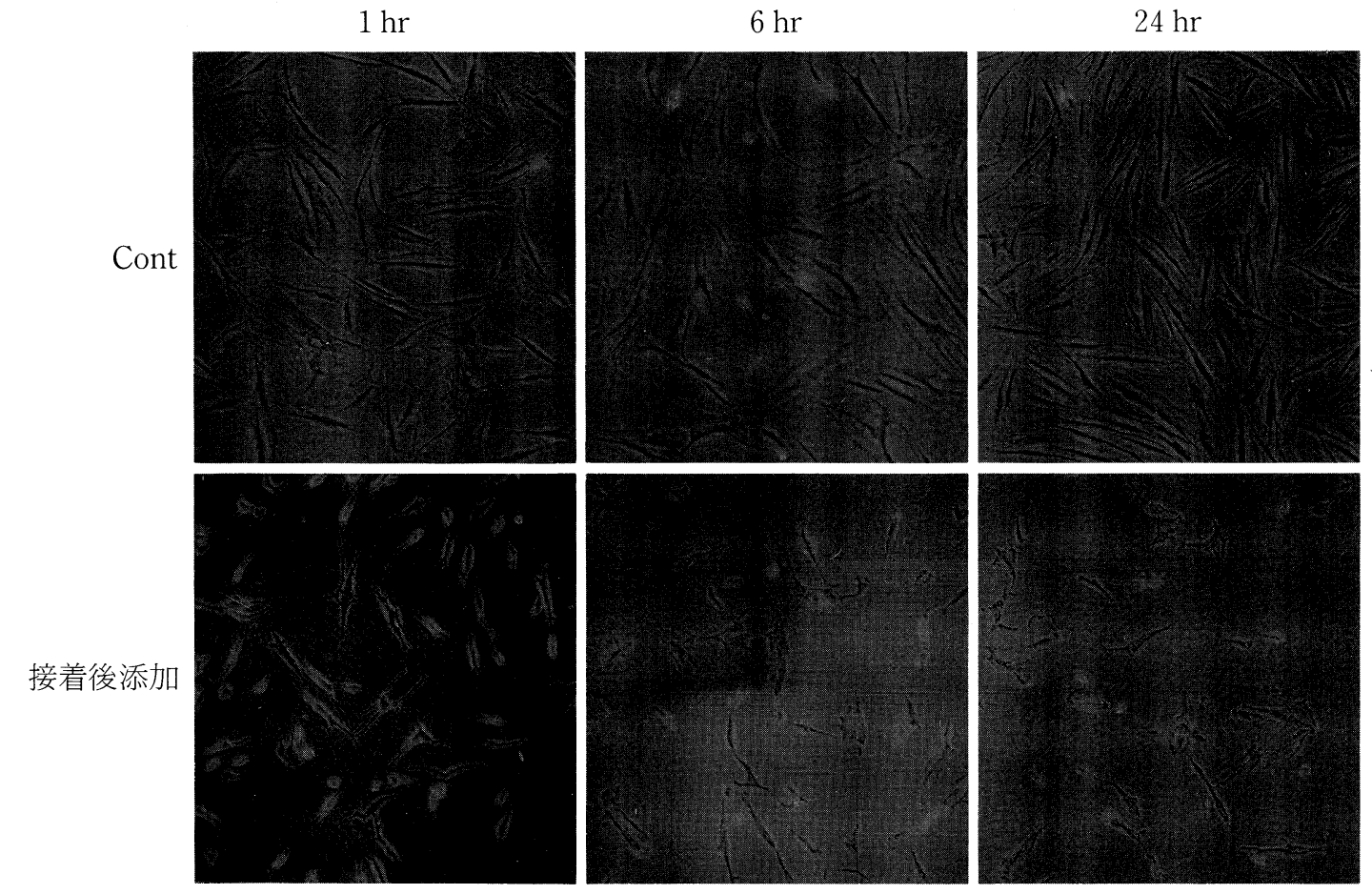

図 5-2 アムロジピンによる歯肉線維芽細胞の形態変化 $(\mathrm{n}=3)$

コントロール； 1 時間後, 6 時間後, 24 時間後, 細胞は紡鍾形を示し, 細胞分裂像も認められる。 また経時的に細胞数の増加が認められる。
$24 \mathrm{hr}$
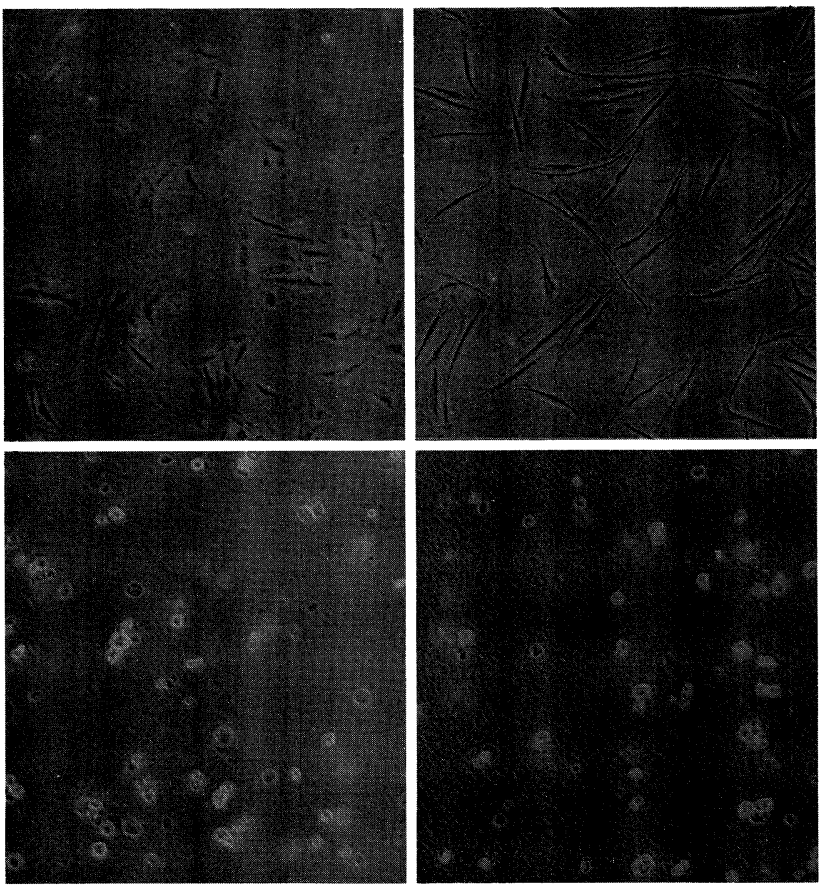

(2) 


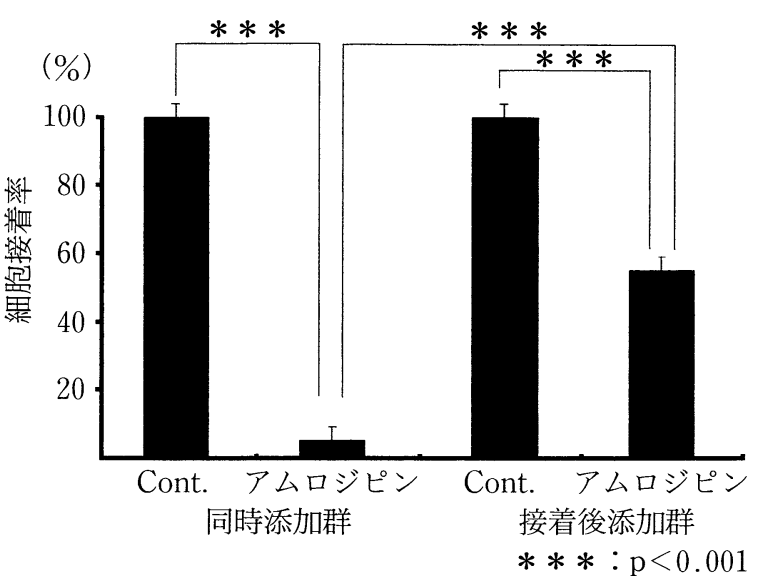

図 6 細胞接着率の変化 $(\mathrm{n}=3)$

アムロジピン添加による接着性細胞の減少は, 添 加方法に関わらず認められたが，同時添加群におい てより顕著であった。

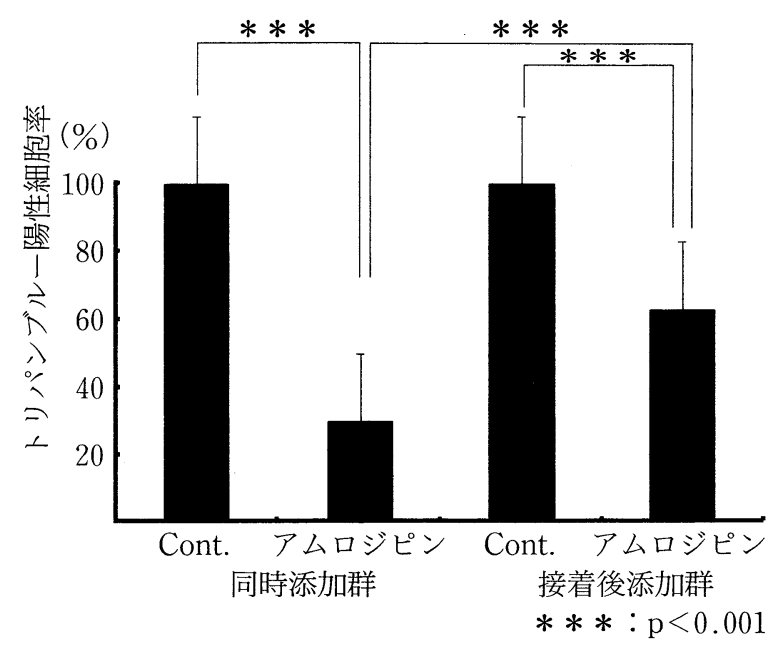

図 7 アムロジピン添加による生細胞率の変化 $(\mathrm{n}=3)$

添加方法に関わらず生細胞の減少が認められ たが，同時添加群においてより顕著であった。

\section{考察}

Ca 拮抗薬は 1970 年代はじめに抗狭心症薬として開

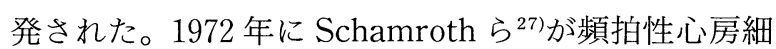
動に応用し, 1974 年に Kinkler とSpurrell ${ }^{28)}$ は発作 性上室性頻拍症に対する効果, 1981 年に Kimura と Kishida $^{29)}$ が異型狭心症等の心疾患に対する効果につ いて報告している。Ca 拮抗薬は従来の降圧薬に比べ, より強力な降圧効果を発揮することに加えて中枢神経 系および代謝系への影響が少ないことで汎用されてき
た ${ }^{30)}$ 。最近，これら Ca 拮抗薬を血管拡張や降圧作用 などの薬効により分類するという流れがある ${ }^{31)}$ 。二

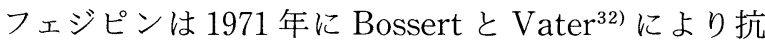
狭心症薬として開発され，1972 年にMurakami ら ${ }^{33)}$ が高血圧合併例に対し降圧作用があると報告し，第 1 世代薬として高血圧の薬物療法に大きな影響を与え， 使用頻度は著しく増加した。ニフェジピンはジヒドロ ピリジン系に分類され，25 年以上にわたって使用さ れてきたが，新規の $\mathrm{Ca}$ 拮抗薬の開発により転換期を 迎えようとしている。第 3 世代の Ca 拮抗薬であるア ムロジピン ${ }^{34)}$ は，循環器疾患では優れた治療効果を発 揮し, 高血圧症や狭心症に対する治療薬として世界中 で広く使用されている。アムロジピンはニフェジピン と比較して, 受容体への結合速度や受容体との解離速 度が非常に緩徐で，血中濃度半減期が 37 時間と極め て長いことが特徵である。さらに作用の発現が緩徐で あるために反射性交感神経刺激作用が比較的弱く，動 悸, 頻脈などの副作用が少ないことが利点とされてい る30)。これら，アムロジピンの副作用の少ない優れた 薬理作用から歯肉増殖作用を生じないのではないかと 期待がもたれたが，その後の研究によって歯肉増殖症 の発症が報告された ${ }^{20 \sim 22) 。 ~}$

これまでにも, ニフェジピンによる歯肉増殖症の in vitro 研究 ${ }^{35 ~ 38)}$ の報告があるが, $\mathrm{Ca}$ 拮抗薬の直接 的な作用点は明らかにされていない。そこで, 本研究 ではアムロジピンが in vitro で歯肉線維芽細胞に及ぼ す影響を検討した。アムロジピンは $10^{-7} \mathrm{M}$ の添加で も歯肉線維芽細胞の増殖を抑制し, $10^{-4} \mathrm{M}$ 添加群に おいて最も顕著に抑制した。これらのアムロジピンに よる細胞増殖の抑制傾向は作用濃度に依存していた。 また，歯肉線維芽細胞の DNA 合成はアムロジピンの 添加濃度依存的に抑制され，細胞増殖曲線で得られた アムロジピン添加による歯肉線維芽細胞の増殖抑制の 結果と密な相関性が認められた。このことから，アム ロジピンによる細胞増殖の抑制は DNA 合成の抑制に よることが示唆された。Ca 拮抗薬と同様に歯肉増殖 症を誘発するダイランチンは, 細胞増殖を活性化する という報告 ${ }^{39,40)}$ がある一方で, Hassel ら ${ }^{41}$ は細胞増 殖には影響しないと報告している。Ca 拮抗薬を用い た実験系では，西川ら ${ }^{35)}$ がニフェジピン誘発性の歯肉 増殖症患者より分離した歯肉線維芽細胞を用いて検討 した結果，高濃度のニフェジピン $\left(10^{-5} \mathrm{M}\right)$ 添加によ り細胞増殖の抑制が認められたと報告した。また，こ れらの作用は, ニフェジピン誘発性の歯肉増殖症を発 症していない患者由来の歯肉線維芽細胞でも同様の結 果 ${ }^{35)}$ を示している。今回の結果でも, アムロジピン添 加した健常者由来の歯肉線維芽細胞は濃度依存的に細 
胞増殖が抑制され, 高濃度添加においても同様の結果 であった。

アムロジピンによる細胞増殖の抑制作用を，細胞の 代謝の面から解析するために歯肉線維芽細胞の基礎酸 素消費を検討した。今回用いた容存酸素測定装置は当 初細菌に対する抗生剤の薬剤感受性試験を目的に開発 されたが，その後癌細胞に対する薬剤感受性について も使用可能であることが明らかにされている。本装置 を使用して測定した結果, 正常線維芽細胞数に依存し た酸素消費量の増加が認められたことから, 正常線維 芽細胞の酸素消費量を測定することも可能であること が示された。アムロジピンを添加すると細胞呼吸は抑 制され, 増殖抑制作用の顕著な高濃度添加群では, 対 照群と比較して著しい酸素消費の抑制が認められた。 これらの結果より，アムロジピンは歯肉線維芽細胞の 基礎代謝を阻害する可能性が示唆された。

プレート上に接着した歯肉線維芽細胞にアムロジピ ンを作用させると, 作用濃度および時間に依存して細 胞が萎縮し, 円形の細胞や浮遊性の細胞が増加した。 また, 歯肉線維芽細胞の播種時にアムロジピンを添加 した同時添加群では, 播種から 24 時間経過してもプ レート上に接着する細胞はほとんど認められなかっ た。さらに, アムロジピンが歯肉線維芽細胞の接着率 に及ぼす影響を検討したところ，接着性細胞は，アム ロジピン添加方法に関わらず減少したが, 同時添加群 においてより顕著であった。 $\mathrm{Ca}^{2+}$ は細胞増殖の開始, $\mathrm{G}_{1} / \mathrm{S}$ 期移行を制御し ${ }^{42)}, \mathrm{Ca}^{2+}$ 結合蛋白により, 細胞 代謝の活性化, 細胞内の遺伝子発現を介して細胞内の 構造変化を引き起こして S 期へ導く ${ }^{43)}$ と考えらてい る。これらのことから Ca 拮抗薬による Ca 代謝阻害 により $\mathrm{G}_{1} / \mathrm{S}$ 期移行がスムーズに行われなかったので はないかと示唆された。さらにアムロジピン添加によ る歯肉線維芽細胞の接着抑制は, 細胞内の Ca シグナ ル伝達経路の異常によって, 接着性蛋白質や細胞骨格 が変調を来たしために誘起されたものと考えられる。 トリパンブルー排斥試験で示された生細胞率は, アム ロジピン同時添加群, 接着後添加群とも対照群と比較 して有意に減少し, 接着阻害が強く認められた。同時 添加において生細胞が著しく減少した。これらの結果 から, アムロジピンは, 細胞内 Ca による情報伝達系 を遮断することにより, 細胞分裂, 酸素消費, 細胞接 着を抑制し, 細胞増殖の抑制と細胞の生存率を減少さ せることが示された。

現在, Ca 拮抗薬とサイトカインや炎症性因子の相 互作用 ${ }^{24,36)}$ による歯肉線維芽細胞の増殖の変化や歯肉 増殖症患者由来組織における歯肉線維芽細胞の増殖因 子 $\mathrm{TGF}-\beta, \mathrm{b}-\mathrm{FGF}$ の産生上昇 ${ }^{44)}$ 等が報告され, 歯
肉増殖症の発症における $\mathrm{Ca}$ 拮抗薬の間接的な歯肉線 維芽細胞の増殖促進が示唆されている。一方，歯肉組 織の大部分を構成する細胞外基質であるコラーゲンや グリコサミノグリカンの Ca 拮抗薬による産生促進と 分解抑制が示され ${ }^{45 ~ 50)}$, 歯肉線維芽細胞の増殖促進 のみに非依存的な歯肉増殖症の成因が示されている。 本研究において, $\mathrm{Ca}$ 拮抗薬であるアムロジピンは歯 肉線維芽細胞の増殖を直接的な作用により抑制した。 以上の知見より，アムロジピンによる歯肉増殖症の発 症機序は, アムロジピンによる直接的な歯肉線維芽細 胞の増殖促進作用ではない可能性が示唆された。

本論文の要旨は, 第 40 回春季日本歯周病学会学術 大会 (1997 年 4 月 24 日), 76 th General Session \& Exhibition of the IADR（1998 年6月 25 日）におい て発表した。

\section{文献}

1) Kimball, O.P. : The treatment of epilepsy with sodium diphenyl hydantoine. J. Am. Med. Assoc., 112: 1244-1245, 1939.

2) Rateitschak-Plüss, E.M., Hefti, A., Lörtscher, R. and Thiel, G.: Initial observation that cyclosporine-A induces gingival enlargement in man. J. Clin. Periodontol., 10:237-246, 1983.

3) Ramon, Y., Behar, S., Kishon, Y. and Engelberg, I. S. : Gingival hyperplasia caused by nifedipine-a preliminary report. Int. J. Cardiol., 5:195-206, 1984.

4) Lederman, D., Lumerman, H., Reuben, S. and Freedman, PD. : Gingival hyperplasia associated with nifedipine therapy. J. Oral Surg., 57:620622, 1984.

5) McGaw, T., Lam, S. and Coates, J. : Cyclosporininduced gingival overgrowth: Correlation with dental plaque scores, gingivitis scores, and cyclosporin levels in serum and saliva. Oral Surg. Oral Med. Oral Pathol., 64 : 293-297, 1987.

6) Pernu, H.E., Pernu, L.M.H., Huttunen, K.R.H., Nieminen, P.A. and Knuuttila, M.L.E. : Gingival overgrowth among renal transplant recipients related to immunosuppressive medication and possible local background factors. J. Periodontol., $63:$ 548-553, 1992.

7) Modéer, T. and Dahllöf, G. : Development of phenytoin-induced gingival overgrowth in noninstituionalized epileptic children subjected to different plaque control programs. Acta. Odontol. Scand., $45:$ 81-85, 1987.

8) Seymour, R.A. and Smith, D.G. : The effect of a 
plaque control programme on the incidence and severity of cyclosporin-induced gingival changes. J. Clin. Periodontol., $18:$ 107-110, 1991.

9) Wondimu, B., Dahllöf, G., Berg, U. and Modéer, T. : Cyclosporin-A-induced gingval overgrowth in renal transplant children. Scan. J. Dent. Res., 101:282-286, 1993.

10) Dahllöf, G. and Modéer, T. : The effect of a plaque control program on the development of phenytoin-induced gingival overgrowth. A 2-year longitudinal study. J. Clin. Periodontol., $13: 845^{-}$ 849, 1986.

11) Tyldesley, W.R. and Rotter, E. : Gingival hyperplasia induced by cyclosporin-A. Br. Dent. J., 157 : 305-309, 1984.

12）岩倉政城，渋谷芳郎，安野陽子，島田義弘：ニフェ ジピン療法を受けている患者の歯肉増殖有病状況に ついての予備的研究. 口腔衛生会誌, 40：53-59, 1990.

13) Hassell, T., O, Donnell, J., Pearlman, J., Tesini, D., Murphy, T. and Best, H. : Phenytoin induced gingival overgrowth in institutionalized epileptics. J. Clin. Periodontol., 11 : 242-253, 1984.

14) Daley, T.D., Wysocki, G.P. and Day, C. : Clincal and pharmacologic correlations in cyclosporineinduced gingival hyperplasia. Oral Surg. Oral Med. Oral Pathol., 62 : 417-421, 1986.

15) Peñarrocha-Diago, M., Bagán-Sebastián, J.V. and Vera-Sempere, F. : Diphenylhydantoin-induced gingival overgrowth in man: A clinico-pathological study. J. Periodontol., 61 : 571-574, 1990.

16) Lombardi, T., Fiore-Donno, G., Belser, U. and Di Felice, R. : Felodipine-induced gingival hyperplasia : a clinical and histologic study. J. Oral Pathol. Med., 20 : 89-92, 1991.

17) Pcrnu, H.E., Oikarinen, K., Hietanen, J. and Knuuttila, M. : Verapamil-induced gingival overgrowth : a clinical, histologic, and biochemic approach. J. Oral Pathol. Med., 18 : 422-425, 1989.

18) Brown, R.S., Sein, P., Corio, R. and Bottomley, W. K. : Nitrendipine-induced gingival hyperplasia. Oral Surg. Oral Med. Oral Pathol., 70 : 593-596, 1990.

19) Bowman, J.M., Levy, B.A. and Grubb, R.V. : Gingival overgrowth induced by diltiazem. Oral Surg. Oral Med. Oral Pathol., 65: 183-185, 1988.

20） Ellis, J.S., Seymour, R.A., Thomason, J.M., Monkman, S.C. and Idle, J.R. : Gingival sequestration of amlodipine and amlodipine-induced gingival overgrowth. Lancet., 341 : 1102-1103, 1993.

21) Seymour, R.A., Ellis, J.S., Thomason, J.M., Monkman, S.C. and Idle, J.R.: Amlodipine-induced gingival overgrowth. J. Clin. Periodontol., 21 : 281-283, 1994.

22) Jorgensen, M.G. : Prevalence of amlodipinerelated gingival hyperplasia. J. Periodontol., 68 : 676-678, 1997.

23）日本組織培養学会編：組織培養の技術，第二版，朝 倉書店, 東京, 1988, 174-177.

24）西川聖二，上野明道，石田 浩，永田俊彦，浜崎章 弘, 幸田直彦, 木戸淳一, 若野洋一：ニフェジピン による歯肉増殖症に関する研究一七卜歯肉線維芽細 胞におけるニフェジピンおよび EGF の増殖に及ぼ す影響一。 日歯周誌, $28 ： 168-175,1986$.

25) Amano, Y., Okumura, C., Yoshida, M., Unten, S., Arai, J., Tagawa, T., Hoshino, S., Hashimoto, H., and Ishikawa, H. : Measuring respiration of cultured cell with oxygen electrode as a metabolic indicator for drug screening. Human Cell., 12:312, 1999.

26) Mclimans, W.F., Davis, E.V., Glover, F.L. and Rake, G.W. : The submerged culture of mammalian cells: The spinner culture. J. Immunol. $79: 428-433,1957$.

27) Schamroth, L., Krikler, D.M. and Garrett, C. : Immediate effects of intravenous verapamil in cardiac arrhymias. Br. Med. J., 1 : 660-662, 1972.

28) Krikler, D.M. and Spurrell, R.A. : Verapamil in the treatment of paroxysmal supraventricular tachycardia. Postgrad. Med. J., $50: 447-453,1974$.

29) Kimura, E. and Kishida, H. : Treatment of variant angina with drug: A survey of 11 cardiology institutes in Japan. Circulation., 63:844-848, 1981.

30）石井當男：Ca 拮抗薬. 臨床と研究, $74 ： 94-98$, 1997.

31) Van Zwieten, P.A. and Karlberg, B.E. : Introduction of amlodipine symposium. J Cardiovasc. Pharmacol., 24 (suppl. B) : v, 1994.

32) Bossert, F. und Vater, W. : Dihydropyridine, eine neue Gruppe stark wirksamer Coronartherapeutika. Naturwissenschaften., 58:578, 1971.

33) Murakami, M., Murakami, E., Takekoshi, N., Tsuchiya, M., Kin, T., Onoe, T., Takeuchi, N., Funatsu, T., Hara, S., Ishise, S., Mifume, J. and Maeda, M. : Antihypertensive effect of $4(-2$, Nitrophenyl) -2, 6-Dimethyl-1, 4-Dihydropyridine-3, 5-Dicarbonic Acid Dimethylester (Nifedipine, Bay-a 1040), a new coronary dilator. Jpn. Heart. J., 13 : 128-135, 1972.

34) Nayler, W.G. : The preclinical of amlodipine : An overview. J. Cardiovasc. Pharmacol., 24 (suppl. B) : S 1-S 5, 1994.

35) Nishikawa, S., Tada, H., Hamasaki, A., Kasaha- 
ra, S., Kido, J., Nagata, T., Ishida, H. and Wakano, Y. : Nifedipine-induced gingival hyperplasia: A clinical and in vitro study. J. Periodontol., 62:30-35, 1991.

36） 戸村真一：ニフェジピン歯肉増殖の関連性に関する 研究-IL-1 存在下でのニフェジピンが培養線維芽 細胞のウロン酸産生に与える影響一. 日歯周誌, $34: 315-322,1992$.

37）石濱済美，中尾寿美，藤井 彰：ニフェジピン投与 による実験的歯肉肥厚に関する研究. 一実験モデル と肥厚部線維芽細胞におけるカルシウム取り込みに 対するカルシウム拮抗薬の影響一. 日大口腔科学, 18:27-37, 1992.

38) Fujii, A., Matsumoto, H., Nakao, S., Teshigawara, H. and Akimoto, Y. : Effect of calciumchannel blockers on cell proliferation, DNA synthesis and collagen synthesis of cultured gingival fibroblasts derived from human nifedipine responders and non-responders. Archs. Oral Biol., 39 : 99-104, 1994.

39) Shafer, W.G. : Response of radiated human ginigval fibroblast-like cell to dilantin sodium in tissue culture. J. Dent. Res., 44：671-677, 1965.

40）松尾 朗, 矢嶋俊彦：培養線維芽細胞の増殖とコラ ゲン線維形成. 歯基礎誌, 27 :53-63, 1985.

41) Hassell, T.M., Page, R.C., Narayanan, A.S. and Cooper, C.G. : Diphenylhydantoin (Dilantin) gingival hyperplasia: Drug-induced abnormality of connective tissue. Proc. Natl. Acad. Sci., $73: 2909$ $-2912,1976$.

42）宇野 功：細胞内調節因子による細胞増殖の制御. 蛋白質核酸酵素, 34：1028-1039, 1989.

43）飯田秀利：カルシウムと G 1 制御. 実験医学, 8 ：
1347-1354, 1990.

44) Saito, K., Mori, S., Iwakura, M. and Sakamoto, S. : Immunohistochemical localization of transforming growth factor $\beta$, basic fibroblast growth factor and heparan sulphate glycosaminoglycan in gingival hyperplasia induced by nifedipine and phenytoin. J. Periodont. Res., 31 : 545-555, 1996.

45) Hassell, T.M. : Evidence for production of an inactive collagenase by fibroblasts from phenytoin-enlarged human gingivae. J. Oral. Pathol., $11: 310-317,1982$.

46) Vernillo, A.T. and Schwartz, N.B. : The effects of phenytoin (5, 5-diphenylhydantoin) on human gingival fibroblasts in culture. J. Periodont. Res., $22: 307-312,1987$.

47) Shikata, H., Utsumi, N., Shimojima, T., Oda, Y. and Okada, Y. : Increased expression of type IV collagen genes in drug-induced gingival enlargement. FEBS., $334:$ 65-68, 1993.

48) Schincaglia, G.P., Forniti, F., Cavallini, R., Piva, R., Calura, G. and del Senno, L. : Cyclosporin-A increases type I procollagen production and mRNA level in human gingival fibroblasts in vitro. J. Oral. Pathol. Med., 21 : 181-185, 1992.

49) Tipton, D.A., Stricklin, G.P. and Dabbous, M.K. : Fibroblast heterogeneity in collagenolytic response to cyclosporine. J. Cell. Biochem., 46 : 152-165, 1991.

50) McCulloch, C.A.G. and Knowles, G.C. : Deficiencies in collagen phagocytosis by human fibroblasts in vitro: A mechanism for fibrosis? J. Cell. Physiol., 155 : 461-471, 1993.

連絡先：

日本歯科大学歯学部歯周病学教室

干 102-8158 東京都千代田区富士見 2-3-16 